Ayurlog: National Journal of Research in Ayurved Science

http://www.ayurlog.com Volume: $6^{\text {th }} \mid$ Issue: $5^{\text {th }} \mid$ August 2018

\title{
Comparative study of standardized apamarga ksharsutra and traditional ksharsutra in the management of bhagandara w. s. r. fistula in ano.
}

\author{
Bharat M. Rokade**1, Umesh A. Vaidya ${ }^{2}$
}

1. Associate Professor,

2. Professor,

Department of Shalya tantra, College of Ayurveda,

Bharati Vidyapeeth Deemed to be University, Pune, India.

*Corresponding author: Email bharatrokade20@ gmail.com ; Mob. NO. 09822552223

\begin{abstract}
:
Fistula in Ano is condition which has been recognized as difficult surgical diseases in all ancient \& modern medical sciences of the world. In Ayurvedic text it is describe as Bhagandara. Ksharsutra is a unique an
\end{abstract} an established procedure for the management of Bhagandara in Ayurveda. It has brought upheaval in the Indian system of Surgery. The aim of the study was to compare standardized or traditional ksharsutra therapy in the management of fistula in Ano.

Materials \& methods- The study was randomized clinical trial carried out at anorectal unit of Shalya tantra department of College of Ayurved, Bharati Vidyapeeth Deemed to be University, Pune. The technique involved passing a medicated seton (Ksharsutra) through fistulous tract. 40 patients with fistula in Ano were selected and divided into two groups of twenty patients each. Group A was treated with standardized ksharsutra and Group B with the traditional ksharsutra.
Result- The healing occurred in all patients treated either with standardized or traditional ksharsutra. The average unit cutting time was 5.8 for standardized ksharsutra and 6.7with traditional sharsutra. Statistical analysis was done.

Keywords- Bhagandara, fistula in Ano, ksharsutra

Introduction (Back ground information)

Bhagandara (Fistula in Ano) at modern parlance is a common anorectal condition prevalent in the populations worldwide and its prevalence is second highest after Arsha (hemorrhoids). Fistula in Ano is a tract lined by granulation tissue which opens deeply in the anal canal or rectum \& superficially around the anus. ${ }^{1}$ Although the four modalities for the treatment of Bhagandara have been described, Kshara is a widely used form. It promises to be an efficient form of treatment ${ }^{2-5}$. Hence this is the field we decided to exploit. In modern science surgery is one of the methods of treating Bhagandara. Kshara Sutra is one 
of the chief modalities in the treatment of Bhagandara in Ayurvedic science. ${ }^{6-7}$

Exploration of the Standardised ksharsutra as a better substitute to traditional ksharsutra is the need of the hour. The rational of the study is to find out an effective alternative as Standardised preparation of Apamarga ksharsutra over a ksharsutra made by traditional method.

Ksharsutra is a scientifically validated treatment in the management of Bhagandara. Ksharsutra treatment heals the fistulous tract with the integrity of sphincters and the existing data reveal negligible chances of recurrence.

The Apamarga ksharsutra is well proven to be an effective treatment for fistula in Ano, so we decided to use Apamarga ksharsutra manufactured with specially designed machine which provides firm and smooth layered ksharsutra. It has als unique packaging which avoids loss of kshara from ksharsutra.

\section{Need of the study}

All previous research was done on various types of ksharsutra and its comparative study and other form of treatment modalities. But here we explored a new manufacturing method for ksharsutra preparation. Its unique trial ever as far as previous study was concerned.

Traditional ksharsutra may loss its coatings and uniformity while packaging. Also may cause infection due to handling. So we decided to use standardized ksharsutra.

CCRAS also prioritized the invention of such ksharsutra made with automated machine.

\section{Aim and Objectives}

Aim: 'To evaluate the efficacy of Standardized Apamarga ksharsutra in the management of Bhagandara'.

Objectives: To compare the clinical efficacy of Standardized Apamarga ksharsutra with traditional ksharsutra.

Hypothesis: Standardized ksharsutra works better than traditional ksharsutra.

\section{Materials and methodology}

The study was randomized clinical trial carried out at OPD/IPD of ano-rectal unit of Shalyatantra department of College of Ayurved, Bharati Vidyapeeth Deemed to be University, Pune. Ethical committee permission was taken prior to study. The technique involved passing a medicated seton (Ksharsutra) through fistulous tract. patients with fistula in Ano (Bhagandara) were selected and divided into two groups of twenty patients each. Group A was treated with standardized ksharsutra and Group B with the traditional ksharsutra

- Group A-

20 patients (Standardised Apamarga ksharsutra)

- Group B- 20 patients. (Traditional ksharsutra)

Preparation of ksharsutra:

Standardized Apamarga ksharsutra prepared with specially designed machine, which gives uniform coating of snuhi latex as well as Apamarga kshara. It also provides unique packaging to avoid loss of kshara from sutra. Traditional ksharsutra prepared according to acharya chakradutta as snuhi and haridra. 


\section{Method of ksharsutra Application:-}

- Pre-operative preparation

- Operative procedure ksharsutra ligation under spinal Anesthesia

- Postoperative measures

- Ksharsutra Changing on every $7^{\text {th }}$ day after ligation of ksharsutra till cutting of tract.

Selection and exclusion criteria of study participants

Inclusion criteria:-

1. Patients having anal fistula were randomly selected.

2. Selection is irrespective of sex, religion \& socio- economical class.

3. Age between 15 to 60 years.

\section{Exclusion criteria:-}

1. Patients having bleeding disorders, patients on anti -coagulation drugs and Ca rectum.

2. Patient of age below 15 year \& above 60 years were excluded.

3. Pregnant women.

4. Chronic or acute ulcerative colitis.

5. Intestinal and pelvic malignancies.

6. Veneral diseases and HIV.

7. Multiple fistulae originating mainly due to Tuberculosis.

8. Crohn's disease.

9. Uncontrolled DM

\section{Efficacy parameters.}

\section{Criteria of Assessment:}

\section{Subjective parameters}

A) PAIN - By visual analogue scale
Pain will be assessed by visual analogue scale.

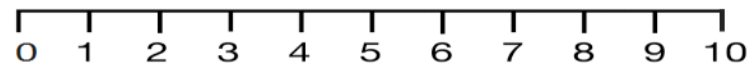

- Mild - 0 - 1

- Moderate - 2-5

- Severe - 6-8

- Unbearable - 9-10

\section{B \} ITCHING ;-}

- No Itching- - 0

- Mild \& occasional- 1

- Moderate \& occasional- 2

- Moderate \& Frequent - 3

- Severe \& continuous - 4

\section{Objective parameters}

\section{DISCHARGE}

- No Discharge - 0

- Mild (If wound wet $1 \mathrm{~cm}$ gauze piece)- 1

- Moderate (If wound wet $2 \mathrm{~cm}$ gauze piece) - 2

- $\quad$ Severe (If wound wet more than 2 cm gauze piece) - 3

- Excruciating (continuous \& profuse) - 4

\section{B \} NATURE OF DISCHARGE}

- Blood -0

- Serous -1

- Purulent- 2

\section{C) LENGTH OF TRACT}

Initially length of tract is measured with the help of probe and length of thread/ksharsutra within the tract then on 
every follow up length of previous ksharsutra within tract is measured with scale and considered as length of tract.

\section{D\} UCT ( UNIT CUTTING TIME)}

$\mathbf{U C T}=$ Total No. of days taken to cut through / Initial length of tract in cms

$$
=\text { Days } / \mathbf{c m s} \text {. }
$$

\section{Investigations}

Routine hematological, biochemical, urine and stool examinations were done to rule out the pathological conditions mentioned above.

\section{Radiological examinations}

1. X-ray chest PA view (if required)

2. Fistulography (in high anal and recurrent fistulae)

3. MR fistulogram (if required and selected cases)

\section{Follow Up:-}

Follow up is taken on $1^{\text {st }}, 7$ th $\& 14^{\text {th }}$ days and observations recorded in a tabular form.

\section{Observations -}

Table 1- Incidence of age

\begin{tabular}{|c|c|c|c|}
\hline $\begin{array}{c}\text { Age } \\
\text { group in } \\
\text { years }\end{array}$ & $\begin{array}{c}\text { No of } \\
\text { patients. } \\
\text { A- Group } \\
\text { (standardized })\end{array}$ & $\begin{array}{c}\text { No of } \\
\text { patients. } \\
\text { B- Group } \\
\text { (Traditional ) }\end{array}$ & Total \\
\hline $\begin{array}{c}\text { Up to } 20 \\
\text { yrs }\end{array}$ & 02 & 01 & 03 \\
\hline $\begin{array}{c}21-30 \\
\text { yrs }\end{array}$ & 06 & 05 & 11 \\
\hline $\begin{array}{c}31-40 \\
\text { yrs }\end{array}$ & 08 & 09 & 17 \\
\hline $\begin{array}{c}41-50 \\
\text { yrs }\end{array}$ & 02 & 03 & 05 \\
\hline
\end{tabular}

\begin{tabular}{|c|c|c|c|}
\hline $\begin{array}{c}51 \text { and } \\
\text { above }\end{array}$ & 02 & 02 & 04 \\
\hline TOTAL & 20 & 20 & 40 \\
\hline
\end{tabular}

Table 2- Incidence of Sex

\begin{tabular}{|c|c|c|c|}
\hline Sex & $\begin{array}{c}\text { No of } \\
\text { patients. } \\
\text { A-Group } \\
\text { (standardized })\end{array}$ & $\begin{array}{c}\text { No of } \\
\text { patients. } \\
\text { B-Group } \\
\text { (Traditional })\end{array}$ & Total \\
\hline Male & 13 & 11 & 24 \\
\hline Female & 07 & 09 & 16 \\
\hline TOTAL & 20 & 20 & 40 \\
\hline
\end{tabular}

Table 3- Types of Bhagandara

\begin{tabular}{|c|c|c|c|}
\hline $\begin{array}{l}\text { Types } \\
\text { of } \\
\text { Bhagandara }\end{array}$ & $\begin{array}{l}\text { No of } \\
\text { patients. } \\
\text { A- Group } \\
\text { (standardiz } \\
\text { ed ) }\end{array}$ & $\begin{array}{l}\text { No of } \\
\text { patients. } \\
\text { B- Group } \\
\text { (Tradition } \\
\text { al ) }\end{array}$ & $\begin{array}{l}\text { Tota } \\
1\end{array}$ \\
\hline Shataponaka & 02 & 01 & 03 \\
\hline Ushtragreeva & 03 & 03 & 06 \\
\hline Parisravi & 11 & 14 & 25 \\
\hline $\begin{array}{c}\text { Shambhukavar } \\
\text { ta }\end{array}$ & 03 & 02 & 05 \\
\hline Unmargi & 01 & 00 & 01 \\
\hline TOTAL & 20 & 20 & 40 \\
\hline
\end{tabular}

Table 4- Types of Fistula in Ano

\begin{tabular}{|l|l|l|l|}
\hline $\begin{array}{l}\text { Types of } \\
\text { Fistula in } \\
\text { Ano }\end{array}$ & $\begin{array}{l}\text { No of } \\
\text { patients. } \\
\text { A- Group } \\
\text { (standardize } \\
\text { d ) }\end{array}$ & $\begin{array}{l}\text { No of } \\
\text { patients. } \\
\text { B-Group } \\
\text { (Traditiona } \\
1 \text { ) }\end{array}$ & $\begin{array}{l}\text { Tota } \\
1\end{array}$ \\
\hline $\begin{array}{l}\text { Sub } \\
\text { cutaneou } \\
\text { s }\end{array}$ & 03 & 04 & 07 \\
\hline $\begin{array}{l}\text { Sub } \\
\text { mucous }\end{array}$ & 05 & 03 & 08 \\
\hline Low anal & 10 & 12 & 22 \\
\hline High anal & 02 & 01 & 03 \\
\hline TOTAL & 20 & 20 & 40 \\
\hline
\end{tabular}

Table 5- Incidence of new and old cases

\begin{tabular}{|c|c|c|}
\hline $\begin{array}{l}\text { New and } \\
\text { old(recurren } \\
\text { ce) cases }\end{array}$ & $\begin{array}{l}\text { No of } \\
\text { patients. } \\
\text { A- Group } \\
\text { (standardiz } \\
\text { ed ) }\end{array}$ & $\begin{array}{l}\text { No of } \\
\text { patients. } \\
\text { B- Group } \\
\text { (Tradition } \\
\text { al ) }\end{array}$ \\
\hline
\end{tabular}




\begin{tabular}{|l|l|l|l|}
\hline New cases & 16 & 18 & 34 \\
\hline $\begin{array}{l}\text { Old/recurren } \\
t \text { cases }\end{array}$ & 04 & 02 & 06 \\
\hline TOTAL & 20 & 20 & 40 \\
\hline
\end{tabular}

Table 6- Incidence of clockwise position of external opening

\begin{tabular}{|c|c|c|c|c|c|c|}
\hline & & & & 0 & 72 & \\
\hline Clockwis & No of & No of & Tota & 10 & $\frac{1.2}{5.8}$ & $\frac{5.2}{6.4}$ \\
\hline e position & patients. & patients. & 1 & 11 & 5.6 & 6.8 \\
\hline & A- Group & B- Group & & 12 & 6.4 & 6.5 \\
\hline $\begin{array}{l}\text { external } \\
\text { opening }\end{array}$ & $\begin{array}{c}\text { d ) } \\
\end{array}$ & $\begin{array}{c}\text { I radiciona } \\
1\end{array}$ & & TOTA & 20 & 20 \\
\hline 1 & 00 & 01 & 01 & & & \\
\hline
\end{tabular}

Table 7 - Incidence of initial length of tract

\begin{tabular}{|c|c|c|c|}
\hline $\begin{array}{c}\text { Initial } \\
\text { length } \\
\text { of tract }\end{array}$ & $\begin{array}{c}\text { No of } \\
\text { patients. } \\
\text { A- Group } \\
\text { (standardized } \\
\text { ) }\end{array}$ & $\begin{array}{c}\text { No of } \\
\text { patients. } \\
\text { B- Group } \\
\text { (Traditional } \\
\text { ) }\end{array}$ & Total \\
\hline $\begin{array}{c}\text { Up to } \\
5 \mathrm{~cm}\end{array}$ & 12 & 10 & 22 \\
\hline $\begin{array}{c}5.1- \\
10 \mathrm{~cm}\end{array}$ & 04 & 07 & 11 \\
\hline $\begin{array}{c}10.1- \\
15 \mathrm{~cm}\end{array}$ & 03 & 02 & 05 \\
\hline $\begin{array}{c}\text { Above } \\
15 \mathrm{~cm}\end{array}$ & 01 & 01 & 02 \\
\hline TOTAL & 20 & 20 & 40 \\
\hline
\end{tabular}

Table 8 - Incidence of UCT with different clockwise position

\begin{tabular}{|c|c|c|}
\hline Clock & UCT & UCT \\
wise & A- Group & C- Group \\
positio & B- (standard & D- (Traditi \\
n & ized ) & onal ) \\
\hline
\end{tabular}

Table 9 - Average UCT in both groups

\begin{tabular}{|ll|l|}
$\begin{array}{l}\text { Standardized } \\
\text { ksharsutra } \\
\text { Group }\end{array}$ & $\mathbf{5}$ & $\mathbf{\text { A }}$ \\
\hline $\begin{array}{l}\text { Traditional } \\
\text { ksharsutra } \\
\text { Group }\end{array}$ & $\mathbf{B}$ & $\mathbf{6 . 7}$ \\
\hline
\end{tabular}

\begin{tabular}{|c|c|c|}
\hline 1 & 5.7 & 6.9 \\
\hline 2 & 6.2 & 6.5 \\
\hline 3 & 5.5 & 7.4 \\
\hline 4 & 5.8 & 6.7 \\
\hline 5 & 5.5 & 6.9 \\
\hline 6 & 5.7 & 7.5 \\
\hline 7 & 5.3 & 6.8 \\
\hline 8 & 6.5 & 7.0 \\
\hline 9 & 7.2 & 5.2 \\
\hline 10 & 5.8 & 6.4 \\
\hline 11 & 5.6 & 6.8 \\
\hline 12 & 6.4 & 6.5 \\
\hline $\begin{array}{c}\text { TOTA } \\
\text { L }\end{array}$ & 20 & 20 \\
\hline
\end{tabular}

iscussion

1) Incidence of fistula in ano is more common in the age group 31-40 years.(Table no.1)

2) Males are more prone to Bhagandar i.e. fistula in ano as compared to females. (Table no.2)

3) In this study maximum patients having parisravi bhagandar were recorded as compared to other type of Bhagandar. .(Table no.3)

4) Maximum patients of low anal fistula were recorded during the study as far as types of fistula are concerned. .(Table no.4)

5) New or fresh cases are more in numbers as compared to old or recurrent cases. .

(Table no.5)

6) 5 clock position of external opening is found in maximum 8 patients compared to other position. .(Table no.6) 
7) Initial length of tract i.e. up to $0-5 \mathrm{~cm}$ is recorded in maximum 22 patients. .(Table no.7)

8) Maximum UCT in Group A was 7.2 at 90 clock position\& minimum UCT was 5.3 at 70 clock position.

9) Maximum UCT in Group B was 7.5 at 60 clock position\& minimum UCT was 5.2 at 90 clock position.

\section{Conclusion:}

Average UCT in group of standardized ksharsutra is 5.8.Average UCT in group of Traditional ksharsutra is 6.7. So results indicates that standardized ksharsutra is statistically more effective than traditional ksharsutra.

\section{References:}

1. Norman S.Williams, Bulstrode. Baily \& loves Short practices of Surgery.25 th edition London: Hodder Arnold publishers; 2010.pp.1264

2. Acharya Sushruta, Sushruta Samhita Dalhana, Nibandhasangrah commentary, Edited by Jadavji Trikamji Acharya and Naarayana Ram Acharya; Varanasi: Chaukhambha Sanskrit Sansthan; Reprint 2013; Nidaanasthana 4/312, Pp 824, p280-282

3. Acharya Sushruta, Sushruta Samhita, Dalhana, Nibandhasangraha commentary, Edited by Jadavji Trikamji Acharya and Naarayana Ram
Acharya; Varanasi: Chaukhambha Sanskrit Sansthan; Reprint 2013; Chikitsasthana 17/29-33, Pp 824, p468.

4. Acharya Agnivesha, Charaka Samhita, revised by Charaka \& Dridabala, with Ayurveda Dipika commentary of Chakrapanidatta, Edited by Jadavji Trikamji Acharya; Varanasi: Chaukhambha Prakashan; Reprint 2013; Chikitsasthana 12/96- 97, Pp738, p490.

5. Acharya Vruddha Vagbhata, Ashtanga Samgraha; with the Sasilekha commentary by Indu, Prologue by Prof.Jyotir Mitra, Edited by Dr. Shivprasad Sharma; Varanasi: Chowkhamba Sanskrit series office; Reprint 2008; Uttarasthana 33/2-44, Pp 965, p797-803

6. Shri Chudamani Mishra,Rasakamdhenu with Suvritta Hindi Commentry, Edited by Acharya shri Gulraj Mishra; Varanasi: Chowkhamba Orientalia; Chikitsaadhikar 49/1-2,Pp 329

7. Chakrapanidatta, Chakradatta; with the Vaiyaprabha Hindi Commentary by Dr. Indradeva Tripathi, Edited by Prof. Ramanath Dwivedy; Varanasi: Chaukhambha Sanskrit Bhawan; Reprint2010; Nadivrana chikitsa/12-13, p269272.

Cite article:

Comparative study of standardized apamarga ksharsutra and traditional ksharsutra in the management of bhagandara w. s. r. fistula in ano.

Bharat M. Rokade, Umesh A. Vaidya

Ayurlog: National Journal of Research in Ayurved Science- 2018; (6)(5): 1-6 